\title{
PENGARUH BRAND IMAGE DAN PERSONAL SELLING TERHADAP PURCHASE INTENTION \\ (Studi Kasus di Institut Manajemen Wiyata Indonesia)
}

\author{
Bambang Somantri \\ Program Studi Manajemen, Institut Manajemen Wiyata Indonesia \\ bsomantri@imwi.ac.id \\ Ane Nurranti Awalia \\ Program Studi Manajemen, Institut Manajemen Wiyata Indonesia \\ Anenra119@gmail.com
}

\begin{abstract}
The purpose of this study to determine the effect of the dimensions or variables, brand image and personal selling to purchase intention. Design / methodology / approach: The research method used survey method using questionnaires distributed to 118 sample. While quality testing instruments Techniques include test validity and reliability testing. And techniques of data analysis using descriptive analysis and correlation, while to test the hypothesis, partial analysis ( $T$ test) and simultaneous ( $F$ test) are used. Results: Where as the two independent variables have a significant positive impact on purchase intention which is the brand image and personal selling. Study limitations / implications: The analysis was only performed on one branch and only two dimensions or variables are tested. Expected application of the marketing mix can be formulated and adapted to local environmental conditions and culture in order to be implemented.
\end{abstract}

Keywords: marketing mix; brand image; personal selling; purchase intention

\section{Pendahuluan}

Pendidikan di Indonesia mempunyai peranan yang sangat penting dalam meningkatkan kualitas sumber daya manusia dan merupakan faktor yang sangat fundamental dalam upaya meningkatkan kualitas kehidupan sehingga pendidikan menjadi sarana yang strategis dalam meningkatkan harkat martabat suatu bangsa (Student Journalism Gunadharma University, 2017).

Pendidikan, termasuk di dalamnya adalah perguruan tinggi yang merupakan kunci bagi suatu bangsa untuk meningkatkan kualitas sumber daya manusia sekaligus kualitas bangsanya (Student Journalism Gunadharma University, 2017).

Perguruan tinggi merupakan satuan penyelenggara pendidikan tinggi sebagai tingkat lanjut dari jenjang pendidikan menengah dijalur pendidikan formal, hal ini sesuai dengan pengertian Perguruan Tinggi menurut UU No. 20 tahun 2003 pasal 19 ayat 1 yang menyatakan bahwa: Perguruan Tinggi merupakan jenjang pendidikan setelah pendidikan menengah mencakup program pendidikan Diploma, Sarjana, Magister, Spesialis dan Doktor yang diselenggarakan oleh Perguruan Tinggi (UU No. 20 Tahun 2003 Pasal 9:1, 2017).

Perguruan Tinggi yang ada di Indonesia dapat berbentuk universitas, institut, sekolah tinggi, politekik dan akademik. Data Kemenristekdikti menunjukan jumlah Perguruan Tinggi di Indonesia adalah 4591 perguruan tinggi, baik Perguruan Tinggi Negeri maupun Swasta (Data Kemenristekdikti Jumlah PerguruanTinggi di Jawa Barat Tahun 2015, 2017b). Secara lengkap Data Jumlah 
Perguruan Tinggi di Indonesia disajikan pada Gambar 1. sebagai berikut:

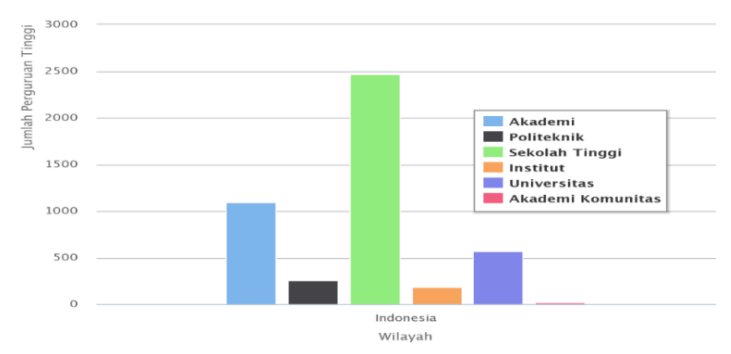

Gambar 1

Data Kemenristekdikti Jumlah Perguruan

Tinggi di Indonesia Tahun 2015

Sumber: www.forlap.ristekdikti.go.id

Dari data gambar atau grafik di atas secara rinci dijelaskan bahwa jumlah Perguruan Tinggi di Indonesia yaitu: Akademik sebanyak 1090, Politeknik sebanyak 258, Sekolah Tinggi sebanyak 2469, Institut sebanyak 187, Universitas sebanyak 571, serta Akademik Komunitas sebanyak 16 ("Data Kemenristekdikti Jumlah PerguruanTinggi di Jawa Barat Tahun 2015," 2017a). Sedangkan berdasarkan data Kopertis IV wilayah Jawa Barat secara lengkap disajikan pada Gambar 2. sebagai berikut:

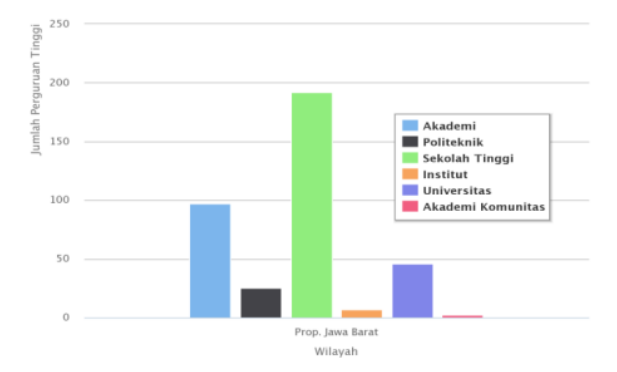

Gambar 2

Data Kemenristekdikti Jumlah Perguruan

Tinggi di Jawa Barat Tahun 2015

Sumber: www.forlap.ristekdikti.go.id
Dari data gambar di atas dijelaskan bahwa, di Jawa Barat saat ini ada sebanyak 369 perguruan tinggi. Secara rinci jumlah Perguruan Tinggi di Jawa Barat yaitu: Akademik sebanyak 97, Politeknik sebanyak 25, Sekolah Tinggi sebanyak 192, Institut sebanyak 7, Universitas sebanyak 46, serta Akademik Komunitas sebanyak 2 ("Data Kemenristekdikti Jumlah PerguruanTinggi di Jawa Barat Tahun 2015," 2017a).

Pemaparan di atas mengenai jumlah Perguruan Tinggi di Indonesia khusunya di Jawa Barat menunjukkan tingkat persaingan pemasaran jasa pendidikan sangat tinggi, sedangkan Perguruan Tinggi di Kota dan Kabupaten Sukabumi sebanyak 35 Perguruan Tinggi akan berdampak pada ketatnya persaingan dalam memperoleh calon mahasiswa.

Kondisi ini mengakibatkan setiap lembaga pendidikan (PTN/PTS) harus bersaing ketat dalam hal mendapatkan peserta didik atau mahasiswa yang nantinya dipersiapkan juga untuk menjadi lulusan yang siap kerja sehingga bisa mengurangi angka pengangguran di Indonesia. Berbagai potensi dan keunggulan yang dimiliki Perguruan Tinggi akan dikerahkan semaksimal mungkin dan menjadi nilai jual yang positif, tetapi sebaliknya perguruan tinggi yang tidak mampu dan tidak memiliki daya saing akan merasakan dampak dari persaingan ini berupa kurangnya jumlah mahasiswa, permasalahan penurunan minat terjadi juga pada Perguruan Tinggi Swasta, khusunya pada PTS di Kota/Kabupaten Sukabumi (Sitepu, 2016).

Berdasarkan pengamatan awal pada kampus IMWI di Kota Sukabumi selain sistem pendidikan nya sudah berstandar Dikti juga memiliki kemampuan vokasi 
dan berkarakter kebangsaan, kampus IMWI memiliki program kelas unggulan dan program kelas karyawan, juga memiliki keunggulan lainnya yaitu program akses kerja sebelum lulus (khusus kelas unggulan) dan pembekalan jiwa wirausaha untuk seluruh mahasiswa di kelas unggulan dan kelas karyawan, namun selama 2 tahun kebelakang menunjukan permasalahan yang cukup serius karena mengalami penurunan jumlah mahasiswa yang cukup signifikan di kelas unggulan (Administrator, 2019).

Pada tahun 2014 jumlah mahasiswa yang terdaftar di kelas unggulan sebanyak 95 orang. Namun pada tahun 2016 terjadi penurunan jumlah mahasiswa menjadi 67 orang (IMWI, 2017). Secara lengkap data jumlah mahasiswa Institut Manajemen Wiyata Indonesia disajikan pada tabel 1. sebagai berikut:

Tabel 1

Data Mahasiswa IMWI Kelas Unggulan Tahun Ajaran 2014 s/d 2016

\begin{tabular}{cccccc}
\hline No & Angkatan & Target & $\begin{array}{c}\text { Jumlah Awal } \\
\text { Mahasiswa }\end{array}$ & $\begin{array}{c}\text { N.A } \\
\text { (Keluar) }\end{array}$ & $\begin{array}{c}\text { Jumlah } \\
\text { Mahasiswa } \\
\text { Aktif }\end{array}$ \\
\hline 1 & Tahun 2014 & 180 & 95 & 37 & 58 \\
\hline 2 & Tahun 2015 & 180 & 81 & 49 & 32 \\
\hline 3 & Tahun 2016 & 180 & 67 & 39 & 28 \\
\hline & Total & 540 & 243 & 125 & 118 \\
\hline
\end{tabular}

Sumber: Data Akademik Institut Manajemen Wiyata Indonesia 2014-2016

Dari data tabel di atas, dapat kita lihat bahwa penurunan jumlah mahasiswa IMWI di Kelas unggulan terjadi setiap tahunnya, bahkan tidak sedikit juga mahasiswa yang gugur ditengah perjalanan kuliah. Rendahnya penerimaan calon mahasiswa baru yang berdampak pada pencapaian jumlah mahasiswa merupakan suatu permasalahan, sehingga peneliti merasa penting untuk mengkaji ulang permasalahan ini. Keputusan pembelian (purchase intention) atau minat calon mahasiswa yang telah dan tetap bertahan menjadi mahasiswa IMWI dengan demikian perlu diteliti.

\section{Tinjauan Pustaka}

\section{Brand Image}

Brand atau merek adalah nama, istilah, tanda, simbol, atau rancangan atau kombinasi hal-hal tersebut, yang dimaksudkan untuk mengidentifikasi barang dan jasa dari seorang atau kelompok penjual dan untuk membedakannya dari produk pesaing (Kotler, 2009).

Merek adalah salah satu kunci keberhasilan sebuah produk, tanpa sebuah merek, produk hanya bisa mengandalkan keberuntungan saja. Meski memperhatikan pembentukan merek, perusahaan juga harus mengkombinasikan berbagai aspek dari merek itu sendiri dan apabila perusahaan hanya memfokuskan pada satu aspek merek saja, tujuan perusahaan dalam pembentukan merek di benak konsumen tidak akan tercapai. Mempromosikan merek hanya berdasarkan satu atau beberapa manfaatnya akan beresiko bagi perusahaan dalam pembentukan merek 
(Kotler, 2009). Citra merek (Brand Image) adalah The set of held about a particular brand is known as the brand image (Kotler, 2009). Brand image diperkuat oleh tindakan pemasaran yang secara konsisten menyampaikan arti suatu merek dalam hal berikut ini:

a. Produk apa yang direpresentasikan oleh merek, apa manfaat inti yang diberikan, serta kebutuhan apa saja yang dipenuhi.

b. Bagaimana merek membuat produk menjadi unggul, dimana asosiasi merek yang kuat, disukai dan unik harus berada pada pikiran konsumen.

\section{Indikator Brand Image}

Menurut David Aaker dan Alexander L. Biel dalam (Tambrin, 2010) bahwa indikator citra merek terdiri dari tiga komponen sebagai berikut:

a. Citra Pembuat (Corporate Image) yaitu: sekumpulan asosiasi yang dipersepsikan konsumen terhadap perusahaan yang membuat suatu produk (barang dan jasa). Citra pembuat meliputi: Popularitas, Kredibilitas dan Jaringan Perusahaan.

b. Citra Pemakai (User Image) yaitu: sekumpulan asosiasi yang dipersepsikan konsumen terhadapemakai yang menggunakan produk (barang atau jasa), meliputi

c. pemakai itu sendiri dan status sosialya.

d. Citra Produk (Product Image) yaitu: sekumpulan asosiasi yang dipersepsikan konsumen terhadap suatu produk (barang atau jasa), yang meliputi atribut produk tersebut, manfaat bagi konsumen, penggunaannya, serta jaminan. Citra produk meliputi: atribut dari produk, manfaat bagi konsumen, serta jaminannya.

\section{Personal Selling}

Penjualan personal (personal selling) adalah salah satu profesi yang paling tua di Dunia, orang-orang yang melakukan penjualan mendapat banyak sebutan: Wiraniaga, perwakilan penjualan, manajer distrik, account executive, konsultan penjualan, sales engineer, agen, dan account development reps adalah beberapa diantaranya (Kotler, 2009) menyatakan "personal selling merupakan presentasi pribadi oleh wiraniaga perusahaan dengan tujuan melakukan penjualan dan membangun hubungan dengan pelanggan.

Menurut (Kotler, 2009), untuk mengukur variable personal selling, digunakan indikator-indikator sebagai berikut (Kotler, 2009).

1) Pendekatan:

Dalam tahapan ini wiraniaga harus mengetahui bagaimana cara menemui dan menyapa pembeli untuk memulai hubungan baik. Pada tahapan ini berbagai pendekatan dapat digunakan untuk menarik perhatian calon pembeli dan memulai penyajian produk. Cara pendekatan disini mencakup penampilan wiraniaga, cara memulai pembicaraan sehingga pembeli berminat terhadap produk yang diuraikan oleh wiraniaga tersebut.

2) Presentasi:

Dalam tahap ini wiraniaga diharuskan untuk menguraikan atau 
memberi informasi mengenai produknya kepada konsumen dengan menerangkan manfaat serta keistimewaan dari produk yang ditawarkanya.

3) Mengatasi keberatan

Dalam tahap ini wiraniaga harus dapat mengatasi keberatan yang diajukan oleh konsumen melalui pendekatan yang positif, meminta pembeli menjelaskan penolakkannya, mengajukan pertanyaan sedemikian rupa sehingga pembeli harus memberi alasan penolakkannya, menyangkal alasan penolakan pembeli, atau mengubah keberatan menjadi alasan untuk membeli.

4) Penutupan
Dalam tahap ini wiraniaga harus mampu melakukan penutupan penjualan dengan baik, sehingga konsumen mau melakukan pembelian. Beberapa wiraniaga tidak mencapai tahap ini atau tidak melakukannya dengan baik. Mereka kurang memiliki keyakinan diri atau merasa kurang nyaman untuk meminta pesanan.

5) Tindak lanjut

Tindak lanjut dan pemeliharaan konsumen penting dilakukan jika wiraniaga ingin memastikan kepuasan konsumen dan mengulangi transaksi pembelian. Setelah melakukan penutupan penjualan, wiraniaga harus melengkapi tindak lanjut misalnya dengan menetapkan waktu pengiriman barang, syaratsyarat penjualan dan lain-lain.

\section{Purchase Intention}

Sebelum mengambil keputusan untuk membeli sebuah produk, tentu terlintas minat untuk membeli dalam benak konsumen. Setelah munculnya minat beli dan sumber daya yang memadai konsumen untuk menikmati suatu produk, konsumen akan memutuskan apakah akan membeli produk tersbut atau tidak. Pemasar harus bisa melihat perilaku konsumen seperti yang telah dijelaskan sebelumnya dan mampu memprediksi proses pengambilan keputusan oleh konsumen untuk membuat strategi promosi yang tepat. Keputusan pembelian (purchase intention) merupakan kegiatan individu yang secara langsung terlibat dalam pengambilan keputusan untuk melakukan pembelian terhadap produk yang ditawarkan oleh penjual. Keputusan pembelian adalah tahap dalam proses pengambilan keputusan pembeli, dimana konsumen benarbenar membeli. Menurut (Kotler, 2009) indicator-indikator pengambilan keputusan konsumen adalah sebagai berikut:
1) Pengenalan Kebutuhan
2) Mencari Informasi
3) Mengevaluasi Alternative
4) Mengambil Kepututusan
5) Evaluasi Paska Pembelian

\section{Penelitian Terdahulu}

Penelitian terdahulu yang menunjukkan bahwa brand image dan personal selling memiliki pengaruh positif dan signifikan terhadap purchase intention diperoleh dari hasil penelitian Penelitian yang dilakukakn oleh Enggar dan Augusty pada tahun 2014 dengan judul "Analisis Pengaruh 
Brand Image dan Personal Selling terhadap Keputusan Pembelian pada Produk Human Diagnostic (Studi Kasus pada PT. Putra Airlangga Medika) (Wiem, 2016).

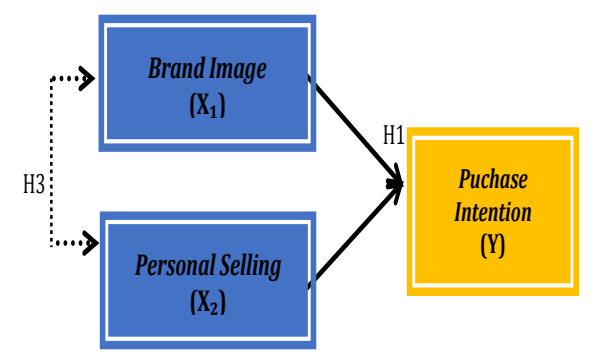

Gambar 3 Model Analisis/Paradigma

Keterangan:

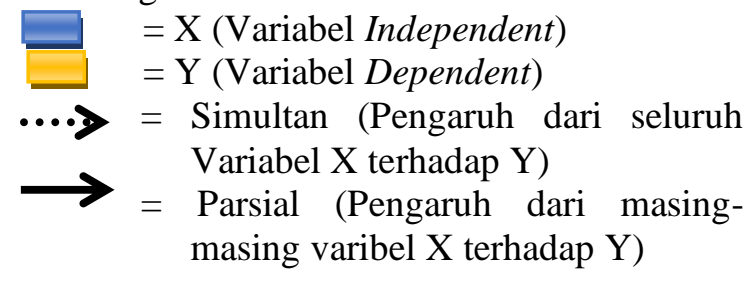

\section{Hipotesis}

1) Hipotesis $\mathrm{Nol}(\mathrm{H} 0)$

$\mathrm{H}_{0}-1$ = Tidak terdapat pengaruh yang positif dan signifikan antara brand image terhadap purchase intenton di Kampus IMWI

$\mathrm{H}_{0}-2$ = Tidak terdapat pengaruh yang positif dan signifikan antara personal selling terhadap purchase intention

$\mathrm{H}_{0}-3$ = Tidak terdapat pengaruh yang positif dan signifikan antara brand image dan personal selling terhadap purchase intention

2) Hipotesis Kerja/Alternatif (Ha)

Ha-1 = Terdapat pengaruh yang positif dan signifikan antara brand image terhadap purchase intention di Kampus IWMI
Ha-2 = Terdapat pengaruh yang positif dan signifikan antara personal selling terhadap purchase intention

Ha-3 = Terdapat pengaruh yang positif dan signifikan anatar brand image dan personal selling terhadap purchase intention di Kampus IWMI

\section{Metode Penelitian}

\section{Tempat dan Waktu Penelitian}

Tempat yang dipilih oleh penulis untuk melakukan penelitiannya yaitu pada institusi pendidikan yaitu Institut Manajemen Wiyata yang beralamatkan di Jl. Gudang No. 7-9 Kota Sukabumi. Pengambilan penelitian dilaksanakan dalam jangka waktu 8 bulan yaitu pada bulan Januari 2018 - Agustus 2018.

\section{Populasi dan Sampel}

Populasi yang terdapat di Institut Manajemen Wiyata Indonesia yaitu sebanyak 118 mahasiswa yang dijadikan sebagai responden. (Arikunto, 2013) mengemukakan populasi adalah keseluruhan subjek penelitian. Apabila seseorang ingin meneliti semua elemen yang ada dalam wilayah penelitian, maka penelitiannya merupakan penelitian populasi (Arikunto, 2013). Studi atau penelitian nya juga disebut studi populasi atau studi sensus. Jumlah mahasiswa yang terdapat di Institut Manajemen Wiyata Indonesia angkatan 2014-2016 yaitu 118 orang (Data Akademik IMWI, 2017), maka yang akan menjadi sampel adalah seluruh mahasiswa IMWI dengan jumlah 118. 


\section{Teknik Pengambilan Data}

Teknik pengambilan data yang digunakan dalam penelitian ini adalah melalui data primer yaitu melalui observasi, wawancara, studi dokumentasi dan secara langsung melakukan penyebaran kuesioner (angket) kepada seluruh mahasiswa/i angkatan 2014-2016 di Institut Manajemen Wiyata Indonesia, sedangkan data sekunder yang digunakan oleh penulis diperoleh dari hasil studi kepustakaaan yang meliputi buku-buku dan data lain yang relevan dengan wilayah penelitian.

\section{Metode Analisis Data}

Metode analisis data yang digunakan dalam penelitian ini yaitu metode deskriptif kuantitatif, Skala Likert yang memiliki skala interval 1 sampai 5. Alat analisis data yang digunakan dalam penelitian ini adalah SPSS (Software Statistical Package of Science) 23 for Windows Version.

\section{Hasil Penelitian dan Pembahasan}

\section{A. Hasil Penelitian}

1. Profil Responden

Penelitian yang telah dilakukan di Institut Manajemen Wiyata Indonesia dengan jumlah responden sebanyak 118 orang, peneliti memperoleh gambaran tentang profil responden penelitian yang dideskripsikan berdasarkan jenis kelamin, program studi dan angkatan. Profil responden berdasarkan Jenis kelamin, program studi dan angkatan dapat dilihat pada tabel 2 berikut ini:

Tabel 2

Profil Responden

\begin{tabular}{llcc}
\hline & Kategori Responden & Jumlah Orang & $\begin{array}{c}\text { Presentase } \\
\boldsymbol{\%}\end{array}$ \\
\hline Jenis & Laki-Laki & 98 Orang & $83,0 \%$ \\
\cline { 2 - 4 } Kelamin & Perempuan & 20 Orang & $17,0 \%$ \\
\hline \multirow{4}{*}{$\begin{array}{l}\text { Program } \\
\text { Studi }\end{array}$} & Manajemen & 42 Orang & $36,0 \%$ \\
\cline { 2 - 4 } & Akuntansi & 33 Orang & $28,0 \%$ \\
\cline { 2 - 4 } & Administrasi Bisnis & 27 Orang & $23,0 \%$ \\
\cline { 2 - 4 } & Sisten Informasi & 10 Orang & $8,0 \%$ \\
\cline { 2 - 4 } & Ilmu Komunikasi & 4 Orang & $3,0 \%$ \\
\hline \multirow{3}{*}{ Angkatan } & Desain Komunikasi Visual & 2 Orang & $2,0 \%$ \\
\cline { 2 - 4 } & 2014 & 58 Responden & $49,0 \%$ \\
\cline { 2 - 4 } & 2015 & 32 Responden & $27,0 \%$ \\
\hline
\end{tabular}

Sumber: Hasil Olah Data 2018

Berdasarkan tabel 2, hasil olah data berdasarkan kategori jenis kelamin menunjukan bahwa jumlah responden yang berjenis kelamin perempuan lebih banyak dari pada responden yang berjenis kelamin laki- laki. Dalam hal ini mengindikasikan bahwa tingginya tingkat kuantitas perempuan yang mendominasi mahasiswa yang kuliah di IMWI. Hasil olah data berdasarkan kategori program studi mayoritas responden 
merupakan mahasiswa/i jurusan Manajemen dan Akuntansi yaitu berjumlah 42 responden $(36 \%)$ dan 33 (28\%). Hal ini dikarenakan kedua jurusan tersebut merupakan jurusan yang paling diminati oleh mahasiswa/i. Sedangkan Administrasi Bisnis berjumlah 27 responden $(23 \%)$. Sistem Informasi 10 responden $(8 \%)$, Ilmu Komunikasi berjumlah 4 responden (3\%) dan Desain Komunikasi Visual 2 responden $(2 \%)$. Hasil olah data berdasarkan kategori angkatan responden terbanyak merupakan mahasiswa/i dari angkatan
2014 yang berjumlah 58 responden atau 49\%, kemudian dari angkatan 2015 berjumlah 32 responden $(27 \%)$ dan 28 responden (24\%) dari angkatan 2016. Hal ini mengindikasikan bahwa responden mayoritas terdapat pada mahasiswa angkatan 2014.

\section{Pengujian Instrumen}

\section{a. Uji Validitas}

(Imam, 2011) mengemukakan bahwa uji validitas digunakan untuk mengukur sah atau valid tidaknya suatu kuesioner (Imam, 2011).

\section{Tabel 3}

Hasil Uji Validitas Variabel Brand Image

\begin{tabular}{|c|c|c|c|c|}
\hline Variabel & Indikator & r hitung & $r$ tabel & Ket \\
\hline \multirow{7}{*}{$\begin{array}{l}\text { Brand } \\
(X 1)\end{array}$} & $\mathrm{X} 1.1$ & 0.452 & 0.36 & Valid \\
\hline & $\mathrm{X} 1.2$ & 0.779 & 0.36 & Valid \\
\hline & $\mathrm{X} 1.3$ & 0.695 & 0.36 & Valid \\
\hline & $\mathrm{X} 1.4$ & 0.822 & 0.36 & Valid \\
\hline & X1.5 & 0.688 & 0.36 & Valid \\
\hline & X1.6 & 0.527 & 0.36 & Valid \\
\hline & X1.7 & 0.703 & 0.36 & Valid \\
\hline \multirow{9}{*}{$\begin{array}{l}\text { Personal } \\
\text { Selling }(X 2)\end{array}$} & $\mathrm{X} 2.1$ & 0.624 & 0.36 & Valid \\
\hline & $\mathrm{X} 2.2$ & 0.706 & 0.36 & Valid \\
\hline & $\mathrm{X} 2.3$ & 0.605 & 0.36 & Valid \\
\hline & $\mathrm{X} 2.4$ & 0.592 & 0.36 & Valid \\
\hline & $\mathrm{X} 2.5$ & 0.568 & 0.36 & Valid \\
\hline & $\mathrm{X} 2.6$ & 0.685 & 0.36 & Valid \\
\hline & $\mathrm{X} 2.7$ & 0.611 & 0.36 & Valid \\
\hline & $\mathrm{X} 2.8$ & 0.793 & 0.36 & Valid \\
\hline & X2.9 & 0.749 & 0.36 & Valid \\
\hline \multirow{9}{*}{$\begin{array}{l}\text { Purchase } \\
\text { Intention (Y1) }\end{array}$} & Y.1 & 0.513 & 0.36 & Valid \\
\hline & Y.2 & 0.765 & 0.36 & Valid \\
\hline & Y.3 & 0.491 & 0.36 & Valid \\
\hline & $Y .4$ & 0.345 & 0.36 & Tidak Valid \\
\hline & Y.5 & 0.359 & 0.36 & Tidak Valid \\
\hline & Y.6 & 0.172 & 0.36 & Tidak Valid \\
\hline & Y.7 & 0.443 & 0.36 & Valid \\
\hline & Y.8 & 0.742 & 0.36 & Valid \\
\hline & Y.9 & 0.735 & 0.36 & Valid \\
\hline
\end{tabular}




\section{b. Uji Reliabilitas}

(Everitt \& Skrondal, 2010) berpendapat, reliabilitas adalah tingkat dimana pengukuran berkalikali terhadap suatu unit akan menghasilkan output yang sama Penelitian ini menggunakan acuan jika koefisien alpha cronbach's yang diperoleh lebih besar dari 0,6 maka kriteria alat ukur yang digunakan adalah baik (andal) (Everitt \& Skrondal, 2010). Perhitungan keandalan alat ukur menggunakan alat bantu program komputer software Statistical Package for Social Science (SPSS) IBM25.

Tabel 4

Hasil Uji Reliabilitas

\begin{tabular}{llll}
\hline Variabel & $\begin{array}{l}\text { Cronbach's } \\
\text { Alpha }\end{array}$ & $\begin{array}{l}\text { Cronsbach's Alpha } \\
\text { yang disyaratkan }\end{array}$ & Keterangan \\
\hline Brand Image & 0.775 & $>0.600$ & Reliabel \\
\hline Personal Selling & 0.836 & $>0.600$ & Reliabel \\
\hline Purchase Intention & 0.743 & $>0.600$ & Reliabel \\
\hline
\end{tabular}

\section{Asumsi Klasik}

a. Uji Normalitas

Menurut (Imam, 2011) mengemukakan bahwa uji normalitas bertujuan untuk mengetahui apakah masing-masing variabel berdistribusi normal atau tidak (Imam, 2011). Uji normalitas diperlukan karena untuk melakukan pengujian-pengujian variabel lainnya dengan mengasumsikan bahwa nilai residual mengikuti distribusi normal. Tabel di bawah ini menunjukan hasil uji normalitas dalam penelitian ini.

Tabel 5

Hasil Uji Normalitas

\begin{tabular}{llr}
\hline \multicolumn{3}{c}{ One-Sample Kolmogorov-Smirnov Test } \\
\hline & & \multicolumn{2}{c}{$\begin{array}{l}\text { Unstandardized } \\
\text { Residual }\end{array}$} \\
\hline $\mathrm{N}$ & & $\mathbf{1 1 8}$ \\
\hline Normal & Mean & $\mathbf{. 0 0 0 0 0 0 0}$ \\
\cline { 2 - 3 } Parameters ${ }^{\text {, b }}$ & Std. Deviation & $\mathbf{2 . 1 9 3 5 7 9 9 0}$ \\
\hline Most Extreme & Absolute & $\mathbf{. 0 5 1}$ \\
\cline { 2 - 3 } Differences & Positive & $\mathbf{. 0 5 1}$ \\
\cline { 2 - 3 } & Negative & $\mathbf{. . 0 3 8}$ \\
\hline Kolmogorov-Smirnov Z & .051 \\
\hline Asymp. Sig. (2-tailed) & $\mathbf{. 2 0 0}$ \\
\hline a. Test distribution is Normal. \\
\hline \multicolumn{3}{l}{ b. Calculated from data. } \\
\hline \multicolumn{3}{c}{ Sumber: Hasil Olah Data 2018} \\
\end{tabular}

Hasil data tabel 5 menunjukkan bahwa pada kolom kolmogrov-smirnov dapat diketahui nilai signifikansi (Asyump.sig 2 tailed) yaitu sebesar 0,20. Nilai signifikansinya lebih besar dari 
$0,05(0,20>0,05)$ maka maka dapat disimpulkan data berdistribusi normal. Dengan demikian, dapat disimpulkan bahwa model regresi pengaruh variabel bebas (brand image) X1 dan (personal selling) X2 secara bersama-sama terhadap (purchase intention) variabel terikat $\mathrm{Y}$ telah memenuhi persyaratan normalitas data.

\section{b. Uji Multikolinearitas}

Uji multikolinearitas menurut (Imam, 2011) bertujuan untuk menguji apakah model regresi ditemukan adanya korelasi antar variabel bebas (independen) (Imam, 2011). Nilai VIF < 10 dan angka tolerance $>0$

Tabel 6

Hasil Uji Multikolineritas

\begin{tabular}{|c|c|c|c|c|c|c|c|c|}
\hline \multicolumn{9}{|c|}{ Coefficients $^{\mathrm{a}}$} \\
\hline & \multirow[t]{2}{*}{ Model } & \multicolumn{2}{|c|}{$\begin{array}{l}\text { Unstandardized } \\
\text { Coefficients }\end{array}$} & \multirow{2}{*}{$\begin{array}{c}\begin{array}{c}\text { Standardized } \\
\text { Coefficients }\end{array} \\
\text { Beta } \\
\end{array}$} & \multirow{2}{*}{$\mathbf{T}$} & \multirow{2}{*}{ Sig. } & \multicolumn{2}{|c|}{$\begin{array}{l}\text { Collinearity } \\
\text { Statistics }\end{array}$} \\
\hline & & B & $\begin{array}{c}\text { Std. } \\
\text { Error }\end{array}$ & & & & Tolerance & VIF \\
\hline 1 & (Constant) & 3.673 & 1.481 & & 2.479 & .015 & & \\
\hline & $\begin{array}{l}\text { BRAND } \\
\text { IMAGE }\end{array}$ & .507 & .054 & .564 & 9.339 & .000 & .884 & 1.131 \\
\hline & $\begin{array}{l}\text { PERSONAL } \\
\text { SELLING }\end{array}$ & 217 & .033 & .397 & 6.576 & .000 & .884 & 1.131 \\
\hline
\end{tabular}

Sumber: Hasil Olah Data Statistik 2019

Jika tolerance value dibawah

0,10 atau VIF diatas 10 maka terjadi multikoloniearitas.

Berdasarkan tabel di atas diketahui bahwa nilai korelasi antar variabel bebas/independen, yaitu variabel $\mathrm{X} 1$ (Brand Image) dan variabel X2 (Personal Selling) mempunyai nilai output VIF yang sama yaitu sebesar 1.131 dan nilai output tolerance masing-masing variabel menunjukkan angka yang sama pula yaitu 0.884 . Setiap variabel bebas mempunyai nilai VIF $<10$ dan nilai tolerance $>0,1$. Jadi dapat disimpulkan bahwa tidak terjadi multikolinieritas antar variabel bebas dalam model regresi ini.

\section{c. Uji Heteroskedastisitas}

Uji heteroskedastisitas menurut (Imam, 2011) bertujuan untuk mengetahui apakah di dalam model regresi terjadi ketidaksamaan variance dari suatu residual pengamatan ke pengamatan lain (Imam, 2011). Grafik scatterplot di samping menunjukkan bahwa diagram pencar yang terbentuk ternyata tidak membentuk suatu pola yang jelas, dan titik-titik menyebar secara acak, tersebar di atas maupun di bawah angka 0 pada sumbu Y. Dengan demikian dapat disimpulkan bahwa tidak terjadi masalah heteroskedatisitas pada model regresi. 


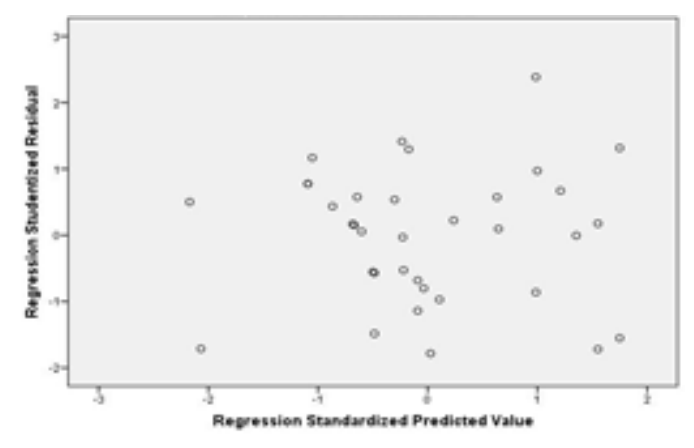

Gambar 3

Hasil Uji

HeteroskedastisitasSumber: Hasil

Olah Data 2017/2018

\section{Pengujian Hipotesis}

\section{Uji Regresi Linear Berganda}

Tabel 7

Analisis Regresi Linier Berganda

\begin{tabular}{|c|c|c|c|c|c|c|}
\hline & \multirow{2}{*}{ Model } & \multicolumn{2}{|c|}{$\begin{array}{c}\text { Unstandardized } \\
\text { Coeffients } \\
\end{array}$} & \multirow{2}{*}{$\begin{array}{c}\text { Standardized } \\
\text { Coeffients }\end{array}$} & \multirow{2}{*}{$\mathbf{T}$} & \multirow{2}{*}{ Sig } \\
\hline & & B & $\begin{array}{l}\text { Std } \\
\text { Eror }\end{array}$ & & & \\
\hline \multirow[t]{3}{*}{1} & (constant) & 3.673 & 1.481 & & 2.479 & .015 \\
\hline & $\begin{array}{l}\text { BRAND IMAGE } \\
\text { PERSONAL SELLING }\end{array}$ & .507 & .054 & .564 & 9.339 & .000 \\
\hline & & .217 & 0.33 & .397 & 6.576 & .000 \\
\hline
\end{tabular}

Sumber: Hasil Olah Data 2018

Hasil analisis dengan menggunakan program SPSS 23 for Windows di atas diperoleh hasil persamaan regresi berganda sebagai berikut: $\quad \mathrm{Y}=18,446-0,043 \mathrm{X} 1+$ $0,619 \mathrm{X} 2$.

Tabel 8

Hasil Uji Koefisien Determinasi

Model Summary ${ }^{\text {b }}$

\begin{tabular}{lcclll}
\hline Model & R & $\begin{array}{c}\text { R } \\
\text { Square }\end{array}$ & $\begin{array}{l}\text { Adjusted } \\
\text { R Square }\end{array}$ & $\begin{array}{c}\text { Std. Error } \\
\text { of the } \\
\text { Estimate }\end{array}$ & $\begin{array}{c}\text { Durbin } \\
\text { Watson }\end{array}$ \\
\hline 1 & $.793 \mathrm{a}$ & .629 & .622 & 2.21257 & 1.594 \\
\hline
\end{tabular}

a. Predictors: (constatant), PERSONAL SELLING, BRAND IMAGE

b. Dependent Variable: PURCHASE INTENTION

Sumber: Hasil Olah Data 2018

Tabel 8 menunjukkan perolehan nilai Adjusted R Square (R2) sebesar $0,622=62,2 \%$, maka dapat disimpulkan bahwa variabel brand image dan personal selling secara bersama-sama 
mempengaruhi variabel purchase intention sebesar $62,2 \%$, sedangkan sisanya sebesar $37,8 \%$ dipengaruhi oleh faktor lain di luar variabel penelitian yang digunakan.

\section{Uji t (Uji Parsial)}

(Imam, 2011) mengemukakan bahwa uji $\mathrm{t}$ digunakan untuk menunjukkan seberapa jauh pengaruh satu variabel penjelas/independen secara individual, dalam menerangkan variasi variabel dependen.

Tabel 9

Hasil Uji t (Parsial)

\begin{tabular}{|c|c|c|c|c|c|c|c|c|}
\hline & \multirow{2}{*}{ Model } & \multicolumn{2}{|c|}{$\begin{array}{c}\text { Unstandardized } \\
\text { Coeffients }\end{array}$} & \multirow{2}{*}{$\begin{array}{c}\begin{array}{c}\text { Standardized } \\
\text { Coeffients }\end{array} \\
\text { Beta }\end{array}$} & \multirow{2}{*}{$\mathbf{T}$} & \multirow{2}{*}{ Sig } & \multicolumn{2}{|c|}{$\begin{array}{l}\text { Collinearit } \\
\text { Y Statistics }\end{array}$} \\
\hline & & B & $\begin{array}{c}\text { Std } \\
\text { Eror }\end{array}$ & & & & $\begin{array}{c}\text { Tole } \\
\text { Ranes }\end{array}$ & VIP \\
\hline \multirow[t]{3}{*}{1} & (constant) & 3.673 & 1.481 & & 2.479 & .015 & & \\
\hline & $\begin{array}{l}\text { BRAND IMAGE } \\
\text { PERSONAL } \\
\text { SELLING }\end{array}$ & .507 & .054 & .564 & 9.339 & .000 & .884 & 1.131 \\
\hline & & .217 & 0.33 & .397 & 6.576 & .000 & .884 & 1.131 \\
\hline
\end{tabular}

Hasil output SPSS pada tabel 8 coeffisiens di atas menunjukkan bahwa variabel brand image (X1) memiliki nilai $t$ hitung sebesar 9.339, pada analisis regresi digunakan probabilitas 2 sisi untuk mengetahui nilai $\mathrm{t}$ tabel, distribusi $\mathrm{t}$ dicari pada a $=5 \%: 2=2,5 \%$ (uji 2 sisi) dengan derajat kebebasan (df) n-k-1 atau 118-3-1 = 114. (n adalah jumlah kurun waktu pada observasi dan $\mathrm{k}$ adalah jumlah variabel), dengan pengujian 2 sisi (signifik ansi $=0,025)$ maka diperoleh hasil untuk t tabel yaitu sebesar 1.65833 . Nilai t hitung variabel brand image lebih besar dari nilai $t$ tabel (9.339 $>1.658)$ dengan tingkat signifikan di atas 0,05 yaitu sebesar $0,00(0,00$ $<0,05)$ maka Ho ditolak dan $\mathrm{Ha}$ diterima. Nilai $\mathrm{t}$ hitung variabel personal selling (X2) lebih besar dari pada nilai $\mathrm{t}$ tabel (6.576 > 1.658) dengan tingkat signifikan di bawah 0,05 yaitu 0,00 , maka Ho ditolak dan $\mathrm{Ha}$ diterima. Cara pengambilan keputusan uji parsial dalam analisis regresi dapat disimpulkan sebagai berikut:

- Terdapat pengaruh yang positif dan signifikan antara brand image (X1) terhadap purchase intention (Y)

- Terdapat pengaruh yang positif dan signifikan antara personal selling (X2) terhadap purchase intention $(\mathrm{Y})$

\section{Uji F (Uji Simultan)}

Imam Ghozali mengatakan bahwa uji $\mathrm{F}$ digunakan untuk mengetahui variabel independen $(\mathrm{X} 1, \mathrm{X} 2, \ldots$, $\mathrm{Xn})$ secara bersama-sama berpengaruh secara signifikan terhadap variabel dependen (Y). Sebuah model dikatakan baik jika nilai $\mathrm{F}$ menunjukkan signifikan. Nilai $F$ signifikan jika signifikansinya lebih kecil dari 0,05 (Imam, 2011). 
Tabel 10

Hasil Uji F (Simultan)

\begin{tabular}{llccccc}
\hline Model & $\begin{array}{c}\text { Sum of } \\
\text { Squares }\end{array}$ & df & Mean Square & F & Sig. \\
\hline 1 & Regress ion & 953.571 & 2 & 476.786 & 97.393 & $.000^{\mathrm{b}}$ \\
\hline Resisuai & 562.980 & 115 & 4.985 & & \\
\hline Total & 1516.551 & 117 & & & \\
\hline
\end{tabular}

Sumber: Hasil Olah Data 2018

Hasil output SPSS pada tabel Anova di atas menunjukkan bahwa variabel brand image dan personal selling memiliki nilai $\mathrm{F}$ hitung yaitu sebesar 97.393 dengan nilai signifikan 0,000. Nilai f-tabel dapat dicari dengan menggunakan tingkat kepercayaan $5 \%$ atau 0,05 dengan rumus df $1=\mathrm{k}-1$, df $2=\mathrm{n}-\mathrm{k}$. Nilai df $1=3-1=2$, dan nilai df 2 $=118-3=115$, maka diperoleh nilai $F$ tabel sebesar 3,08. Kriteria penerimaan hipotesis yaitu Ho ditolak apabila nilai signifikansi kurang dari taraf kesalahan 5\% $(0,05)$ dan nilai $\mathrm{F}$ hitung $>\mathrm{F}$ tabel. Dilhat dari nilai sig $0,00<0,05$ menunjukan bahwa setiap variabel independent (brand imgae dan personal selling) secara bersamasama berpengaruh signifikan terhadap purchase intention (Y) variabel dependent dan nilai $F$ hitung lebih besar dari $\mathrm{F}$ tabel (97.393 > 3,08) maka H0 ditolak dan H1 diterima. Sehingga dapat disimpulkan bahwa terdapat pengaruh positif dan signifikan antara brand image dan personal sellng terhadap purchase intention.

\section{B. Pembahasan}

\section{Pengaruh Brand Image terhadap Purchase Intention}

Penelitian yang dilakukan oleh peneliti menunjukkan hasil bahwa brand image kampsu IMWI memiliki positif dan signifikan terhadap purchase intention atau keputusan mahasiswa dalam memilih tempat kuliah. Hal ini menunjukkan bahwa apabila brand image kampus IMWI semakin ditingkatkan, maka keputusan calon mahasiswa dalam memilih tempat kuliah di IMWI akan semakin meningkat. Brand image menandakan tingkat kualitas tertentu suatu produk sehingga alasan ini lah yange mendorong (perguruan tinggi) untuk selalu memperkuat posisi merek nya agar tercipta brand image yang positif dan mencapat brand image yang kuat dibenak konsumen (calon mahasiswa). Hal ini mendukung hasil penelitian sebelumnya dari penelitian yang dilakukan oleh (Oladepo \& Abimbola, 2015) dalam hasil penelitiannya menyebutkan bahwa citra merek memiliki pengaruh positif yang signifikan terhadap keputusan pembelian. Hal ini dijelaskan juga oleh (Lesmana, 2017) bahwa 
terdapat pengaruuh positif dan signifikan antara citra perusahaan terhadap keputusam pembelian konsumen. Artinya ketika kampus IMWI dianggap memiliki -brand image yang baik maka keputusan mahasiswa untuk memilih kampus IMWI pun akan semakin baik dan meningkat.

\section{Pengaruh Personal Selling} terhadap Purchase Intention

Dalam penelitian ini varibel personal seeling dalam uji parsial (uji t) yang sudah dilakukan bahwa personal selling memiliki pengaruh positif dan signifikan terhadap varibael $\mathrm{Y}$ purchase intention (keputusan pembelian). Hasil ini mendukung pe nelitian sebelumnya yang dilakukan oleh Christina sagala, Mila Destriani, Ulffa Karina Putrid an Suresh Kumar pada tahun 2014, yang menunjukkan hasil bauran promosi berpengaruh positif terhadap keputusan pembelian, kemudian dijelaskan juga oleh (Oladepo \& Abimbola, 2015) menunjukkan bahwa personal selling memiliki pengaruh yang signifikan pada keputusan pembelian konsumen sehingga menyimpulkan bahwa bauran promosi (termasuk di dalam nya personal selling) adalah alat komunikasi pemasaran benar untuk mempengaruhi keputusan pembelian. Oleh karena itu dalam penelitian ini apabila proses personal selling yang dilakukan oleh presenter IMWI dapat dilakukan dengan optimal maka akan mendorong calon mahasiswa dalam melakukan keputusan pembelian atau dalam hal memilih tempat kuliah.

\section{Pengaruh Brand Image dan Personal Selling terhadap Purchase Intention}

Pada Uji Simultan yang dilakukan dalam penelitian ini bahwa brand image \& personal selling secara bersama-sama berpengaruh positif dan signifikan terhadap purchase intention. dengan demikian maka dapat disimpulkan bahwa hipotesis ketiga (Ha-3) diterima. Hal ini mendukung hasil penelitian sebelumnya yang berjudul"The Influence Of Brand Image and Promotional Mix on Consumer Buying Decission" (Oladepo \& Abimbola, 2015) bahwa hasil penelitian nya menunjukkan bahwa cira merek dan personal selling memiliki pengaruh yang signifikan terhadap keputusan pembelian. Penelitian menyimpulkan bahwa cara suatu produk yang dipromosikan ditambah integritas merek produk mendorong konsumen untuk membeli dan melakukan pembelian ulang. Selain itu juga gambar merek dan bauran promosi memberikan pengaruh besar pada keputusan pembelian konsumen sehingga menegaskan bahwa bauran promosi adalah alat komunikasi pemasaran benar untuk mempengaruhi keputusan pembelian konsumen. Artinya apabila kampus IMWI memiliki brand image yang kuat dan didukung oleh proses personal selling yang baik dan optimal 
maka akan mendorong tercapainya keputusan pembelian yang semakin meningkat (dalam hal memilih tempat kuliah).

\section{Simpulan}

Hasil analisis yang telah dilakukan oleh peneliti menyatakan bahwa untuk menjawab pertanyaan dari rumusan masalah yang telah dikemukakan dalam bab sebelumnya, maka telah didapatkan jawaban atas rumusan masalah dan juga simpulan dari penelitian ini, antara lain: (1.) Hasil penelitian di atas menunjukkan bahwa terdapat pengaruh yang positif dan signifikan antara brand image terhadap purchase intention di Kampus IMWI. Hal tersebut ditunjukkan dari nilai $\mathrm{t}$ hitung variabel brand image lebih besar dari nilai $\mathrm{t}$ tabel (9.339 > 1.658) dengan tingkat signifikan di atas 0,05 yaitu sebesar 0,00 $(0,00<0,05)$ maka Ho ditolak dan $\mathrm{Ha}$ diterima. (2.) Hasil penelitian di atas menunjukkan bahwa terdapat pengaruh yang positif dan signifikan antara personal selling terhadap purchase intention di Kampus IMWI. Hal tersebut ditunjukkan dari hasil uji nilai $t$ hitung variabel personal selling (X2) lebih besar dari pada nilai $t$ tabel $(6.576>1.658)$ dengan tingkat signifikan di bawah 0,05 yaitu 0,00, maka Ho ditolak dan Ha diterima. (3.) Hasil penelitian di atas menunjukkan bahwa terdapat pengaruh yang signifikan antara brand image dan personal selling secara simultan terhadap purchase intention di Kampus IMWI. Hal tersebut dilhat dari nilai sig $0,00<0,05$ menunjukan bahwa setiap variabel independent (brand imgae dan personal selling) secara bersama-sama berpengaruh signifikan terhadap purchase intention (Y) variabel dependent dan nilai F hitung lebih besar dari F tabel (97.393 >
3,08) maka H0 ditolak dan H1 diterima. (3.) Hasil penelitian di atas menunjukkan bahwa korelasi/hubungan antara brand image dan personal selling secara simultan dengan purchase intention pada Kampus Institut Manajemen Wiyata Indonesa adalah cukup kuat dengan perolehan nilai Koefisien determinasi atau Adjusted $\mathrm{R}$ square yaitu sebesar 0,622 (R2 = 0,622). Adjusted R square sebesar 0.622 atau $62,2 \%$ hal ini berarti variable dependen purchase intention pada kampus IMWI dapat dijelaskan oleh variabel independen brand image dan purchase intention sedangkan sisanya sebesar 0,378 atau $37,8 \%$ (1 - 0,622 atau 100\% - 62,2\%) dijelaskan oleh variabel-variabel lain yang tidak diperhitungkan dalam penelitian ini.

\section{Saran}

Ditinjau dari perhitungan Weight Mean Score dalam analisis deskripsi, didapat nilai dari tanggapan responden mengenai purchase intention adalah 69\%. Dalam hal ini dapat dijelaskan bahwa menurut tabel interpretasi nilai WMS tersebut tanggapan responden mengenai purchase intention dikategorikan kurang baik. Berdasarkan penelitian ini ditemukan bahwa mayoritas mahasiswa pada perguruan tinggi tertentu tidak bisa menentukan setuju atau tidak setuju (netral) terhadap indikator atau pernyataan mengenai tingkat kepuasan konsumen dalam hal ini mahasiswa dan tingkat merekomendasikan produk. Dalam hal ini pihak manajemen kampus perlu mengevaluasi beberapa indikator dari brand image (indikator tingkat citra status sosial pengguna) yang dalam penelitian ini ditemukan bahwa mahasiswa cukup bangga menjadi bagian dari mahasiswa IMWI namun pada penelitian ini 
menunjukan bahwa rasa bangga nya tidak mempengaruhi pada indikator purchase intention mengenai prilaku pasca pembelian. Dengan demikian perlu adanya evalusi dari pihak manajemen kampus mengingat kepuasan mahasiswa merupakan salah satu hal yang penting dalam pencapaian jumlah calon mahasiswa pada tahun berikutnya, sehingga dengan mahasiswa merasa bangga serta puas dan mampu pada tingkat merekomenadikan produk (dalam hal ini kampus IMWI) maka adanya peningkatan jumlah mahasiswa dapat terjadi pada tahun berikutnya.

\section{Daftar Pustaka}

Administrator. (2019). Program Akses Kerja Imwi Sukabumi.

Arikunto, S. (2013). Prosedur Penelitian Suatu Pendekatan Praktik. Rineka Cipta.

Data Kemenristekdikti Jumlah PerguruanTinggi di Jawa Barat Tahun 2015. (2017a).

Data Kemenristekdikti Jumlah PerguruanTinggi di Jawa Barat Tahun 2015. www.forlap.ristekdikti.go.id.

Everitt, Brian S., \& Skrondal, Anders. (2010). The Cambridge dictionary of statistics.

Imam, Ghozali. (2011). Aplikasi analisis multivariate dengan program IBM SPSS 19. Semarang: Badan Penerbit Universitas Diponegoro, 68.

IMWI, Data Akademik. (2017). Data Akademik IMWI.

Kotler, P. G. A. (2009). Prinsip-prinsip Pemasaran. Edisi 12. Jilid 2. Erlangga.
Lesmana, Rosa. (2017). Pengaruh Citra Perusahaan Terhadap Keputusan Pembelian Konsumen PT. Garuda Indonesia Tbk.(Persero). JIMF (Jurnal Ilmiah Manajemen Forkamma), 1(1).

Oladepo, Onigbinde Isaac, \& Abimbola, Odunlami Samuel. (2015). The influence of brand image and promotional mix on consumer buying decision-a study of beverage consumers in Lagos State, Nigeria. British Journal of Marketing Studies, 3(4), 97-109.

Sitepu. (2016). Jurnal Pendidikan Penabur Yayasan BPK Penabur.

Student Journalism Gunadharma University. (2017). Pentingnya Meneruskan ke Perguruan Tinggi. Gunadharma University. Retrieved from http://wartawarga.gunadarma.ac. id/2010/04/pentingnya-meneruskanke-perguruan-tinggi/,\%0A\%0A\%0A

Tambrin, Mohammad. (2010). Pengaruh Brand Image Terhadap Pelanggan Kartu Simpati Terhadap Kepuasan Mahasiswa Universitas Trunojoyo Madura. Jurnal Studi Manajemen, 4(1), 4-8.

Wiem, E. S. P. A. (2016). Analisis Pengaruh Brand Image dan Personal Selling Terhadap Keputusan Pembelian. 